\title{
The incidence of myocarditis in patients with COVID-19 and in-hospital mortality.
}

\footnotetext{
1. MBBS, FCPS (Cardiology) Assistant Professor Cardiology Nawaz Sharif Medical College, University of Gujrat.

2. MBBS, MD (Gastroenterology) Assistant Professor Gastroenterology Nawaz Sharif Medical College, University of Gujrat.

3. MBBS, FCPS (Cardiology) Senior Registrar

Punjab Institute of Cardiology, Lahore.

4. MBBS, FCPS (Anesthesia) Assistant Professor Anesthesia Nawaz Sharif Medical College, University of Gujrat

5. MBBS, FCPS (Anesthesia) Assistant Professor Anesthesia Nawaz Sharif Medical College, University of Gujrat.

6. MBBS

Medical Officer

Aziz Bhatti Shaheed Teaching Hospital.
}

Correspondence Address:

Dr. Irfan Younus

Department of Gastroenterology

Aziz Bhatti Shaheed Teaching Hospital,

NSMC/ UOG Gujrat.

irfanyounis7887@gmail.com

Article received on:

29/09/2020

Accepted for publication:

$12 / 02 / 2021$

\section{INTRODUCTION}

Corona virus infection has become a recognized infectious disease spreading throughout the world. Number of patients with COVID-19 are increasing day by day in whole globe. Previous studies showed that COVID-19 results in rapid detoriation in patients suffering from chronic illness. ${ }^{1-4}$ According to Huang etal ${ }^{5}, 12 \%$ of patients with COVID-19 were having acute myocardial injury. In another study, out of 138 patients admitted with COVID-19, 16\% had arrhythmias and $7.2 \%$ were having acute myocardial injury. ${ }^{6}$ It was also noted that cardiovascular patients hospitalized with COVID-19 are at greater risk of myocardial injury and poor in-hospital outcome. ${ }^{7}$ Myocarditis (inflammation of the heart muscle) can be identified clinically or histopathologically.
In many studies it was observed that COVID 19 can cause myocarditis ${ }^{8}$ that's why several cases of myocarditis noted after COVID-19.9,10 Myocarditis is an acute severe heart failure which can result in hypotension and cardiogenic shock having high mortality upto $50-70 \%{ }^{8}$ Myocardits can be diagnosed clinically and by imaging aid. Echocardiography is an important tool to assess left ventricular function and to diagnose myocarditis. ${ }^{11} \mathrm{MRI}$ is very useful for the diagnosis of myocarditis. ${ }^{12}$ All these studies were conducted outside Pakistan so in our study we tried to assess the incidence of myocarditis and inhospital mortality in previously healthy population of Pakistan, without any co-morbidities especially cardiovascular diseases. 


\section{MATERIAL \& METHODS}

This was a cross sectional cohort study, 55 patients between 15-70 years of both genders having positive PCR results for COVID-19 were included in this study after informed consent. Whereas patients with prior history of any cardiovascular, pulmonary or other co-morbidity were excluded, patients having hypertension, diabetes or smoking were included in study group. All patients remained admitted and followed up for 14 days. Patients were evaluated clinically, by ECG, troponins and echocardiographically for diagnosis of myocarditis. Incidence of myocarditis and in-hospital mortality was noted. Successful treatment towards hospital discharge was relief of clinical symptoms, a-febrile, clear chest X-Ray and at least two consecutive negative PCR for covid-19. For quantitative variables like age, mean and standard deviations were calculated. For qualitative variables like gender, smoking, hypertension and diabetes Mellitus frequency and percentages were calculated. Stratification was used to control the effect modifiers. After stratification Chi square test was applied to see the effects of the outcome. Data was analyzed with SPSS -23 and $p$ value $<0.05$ was considered as significant.

\section{RESULTS}

A total number of 55 patients were enrolled in the study out of which $45(82 \%)$ were male while $10(18 \%)$ were female. Mean age of patient was $35+10$. Out of fifty five, $5(9 \%)$ patients were diabetics and 4 were hypertensive. Five (9\%) developed mild pneumonia which recovered conservatively and three $(5.4 \%)$ patients developed myocarditis. One (1.8\%) patient expired having myocarditis. Duration of follow up was only during hospital stay. So our in-hospital mortality was $1.8 \%$. P-value was calculated as significant $<0.05$.

\section{DISCUSSION}

Exact incidence of myocarditis is difficult to ascertain in patients of COVID-19. Because this disease is affecting the population of different areas in different ways, in developed countries like America and Europe overall mortality due to COVID-19 is quite high than Asian countries.
Our study was conducted on previously healthy patients; therefore myocarditis was diagnosed in $3(5.4 \%)$ cases of COVID-19 out of which one patient was expired so in-hospital mortality was $1.8 \%$ which is quite low than calculated in a study by Fabre A et al where myocarditis was responsible for sudden cardiac death in $8.6 \%$ of cases and is present in $9 \%$ of routine post partum examination. ${ }^{13}$ The difference may be due to sample size, duration of study, sample technique and baseline characteristics of patients. Incidence of cardiac injury with covid-19 is noted more in previously known cardiac patients.

\begin{tabular}{|c|c|c|}
\hline & \multicolumn{2}{|c|}{ N (\%) } \\
\hline \multicolumn{3}{|l|}{ Age } \\
\hline \multicolumn{3}{|l|}{ Gender } \\
\hline Male & \multicolumn{2}{|c|}{$45(82 \%)$} \\
\hline Female & \multicolumn{2}{|c|}{$10(18 \%)$} \\
\hline \multicolumn{3}{|l|}{ Hypertension } \\
\hline Present & \multicolumn{2}{|c|}{$4(7.2 \%)$} \\
\hline Absent & \multicolumn{2}{|c|}{$51(92.8 \%)$} \\
\hline \multicolumn{3}{|l|}{ Diabetes } \\
\hline Present & \multicolumn{2}{|c|}{$5(9 \%)$} \\
\hline Absent & \multicolumn{2}{|c|}{$50(91 \%)$} \\
\hline \multicolumn{3}{|l|}{ Smoking } \\
\hline Present & \multicolumn{2}{|c|}{$10(18 \%)$} \\
\hline Absent & \multicolumn{2}{|c|}{$45(82 \%)$} \\
\hline \multicolumn{3}{|l|}{ Obesity } \\
\hline Present & \multicolumn{2}{|c|}{$20(36 \%)$} \\
\hline Absent. & \multicolumn{2}{|c|}{$35(64 \%)$} \\
\hline \multicolumn{3}{|c|}{$\begin{array}{l}\text { Table-I. Clinical characteristics of patients in the } \\
\text { study. }\end{array}$} \\
\hline Total Patients & 55 & Mortality \\
\hline With Myocardits & $3(5.4 \%)$ & $1(1.8 \%)$ \\
\hline Without Myocarditis & $52(94.6 \%)$ & 0 \\
\hline
\end{tabular}

In a European study of epidemiology and treatment of cardiac inflammatory diseases $72 \%$ patient had dyspnea, $32 \%$ had chest pain and $18 \%$ had arrhythmia. ${ }^{14}$ Acute myocarditis resembles myocardial infarction with acute chest pain, arrhythmias, and sudden death. ${ }^{15}$ COVID-19 patients may develop severe cardiac 
complications such as myocarditis and heart failure leading to shock. ${ }^{6,8}$ Results of our study were consistent with a study conducted by Peiris JS and colleagues in which incidence of myocarditis in patients with COVID-19 was $0.2-2 \% .{ }^{16}$ Further studies and research work is required to see the effect of this deadly virus on myocardium.

\section{CONCLUSION}

Myocarditis is a known but rare complication of COVID-19. Cardiac injury is more common in patients having cardiovascular diseases and comorbidities. In healthy and immunocompetent population its incidence is quite low.

Copyright(C) 12 Feb, 2021.

\section{REFERENCES}

1. Lu H, Stratton CW, Tang YW. Outbreak of pneumonia of unknown etiology in Wuhan, China: The mystery and the miracle. JMedVirol. 2020; 92(4):401-402.

2. Hui DS, I Azhar E, Madani TA, et al. The continuing 2019-nCoV epidemic threat of novel coronaviruses to global health: The latest 2019 novel coronavirus outbreak in Wuhan, China. Int $\mathrm{J}$ Infect Dis. 2020; 91:264-266.

3. Paules $\mathrm{Cl}$, Marston HD, Fauci AS. Coronavirus infections: More than just the common cold. JAMA. Published online January 23, 2020:707-708.

4. Wuhan Municipal Health Commission. Report of clustering pneumonia of unknown etiology in Wuhan City. Published December 31, 2019. Accessed January 31, 2020:12-31.

5. Huang $C$, Wang $Y, L i X$, et al. Clinical features of patients infected with 2019 novel coronavirus in Wuhan, China. Lancet. 2020; 395(10223):497-506.

6. Wang $\mathrm{D}, \mathrm{Hu} \mathrm{B}, \mathrm{Hu} \mathrm{C}$, et al. Clinical characteristics of 138 hospitalized patients with 2019 novel coronavirus-infected pneumonia in Wuhan, China. JAMA. Published February 7, 2020:1061-1069.
7. Tao Guo, MD; Yongzhen Fan, MD; Ming Chen, MD et al Cardiovascular implications of fatal outcomes of patients with coronavirus disease 2019 (COVID-19). JAMA Cardiol Published online March 27, 2020 AMA Cardiol.

8. Edwards S, Small JD, Geratz JD, Alexander LK, Baric RS. An experimental model for myocarditis and congestive heart failure after rabbit coronavirus infection. J Infect Dis. 1992; 165(1):134-40.

9. Inciardi RM, Lupi L, Zaccone G, et al. Cardiac involvement 1 with coronavirus 2019 (COVID-19) infection. JAMA Cardiol. 2020.

10. Hu H, Ma F, Wei X, Fang Y. Coronavirus fulminant myocarditis saved with glucocorticoid and human immunoglobulin. Eur Heart J. 2020: ehaa190.

11. Felker GM, Boehmer JP, Hruban $R H$, et al. Echocardiographic findings in fulminant and acute myocarditis. J Am Coll Cardiol. 2000; 36(1):227-232.

12. Friedrich MG, Sechtem U, Schulz-Menger J, et al; International Consensus Group on Cardiovascular Magnetic Resonance in Myocarditis. Cardiovascular magnetic resonance in myocarditis: A JACC white paper. J Am Coll Cardiol. 2009; 53(17):1475-1487.

13. Fabre A, Sheppard MN. Sudden adult death syndrome and other non ischaemic causes of sudden cardiac death. Heart. 2006 Mar; 92(3):316-320. Epub 2005 May 27.

14. Hufnagel G, Pankuweit S, Richter A, Schönian U, Maisch B. The European Study of Epidemiology and Treatment of Cardiac Inflammatory Diseases (ESETCID): First epidemiological results. Herz. 2000; 25(3):279-285.

15. Dec GW JR, Waldman H, Southern J, Fallon JT, Hutter AM Jr, Palacios I. Viral myocarditis mimicking acute myocardial infarction. J Am Coll Cardiol.1992; 20(1):85-89.

16. Peiris JS, Chu CM, Cheng VC, et al; HKU/UCH SARS Study Group. Clinical progression and viral load in a community outbreak of corona virus associated SARS pneumonia: A respective study. Lancet. 2003; 361(9371):1767-1772. 


\begin{tabular}{|c|c|c|c|}
\hline \multicolumn{4}{|c|}{ AUTHORSHIP AND CONTRIBUTION DECLARATION } \\
\hline No. & Author(s) Full Name & Contribution to the paper & Author(s) Signature \\
\hline 1 & Muhammad Zahid Ali & Concept, Data collection, & \\
\hline & & $\begin{array}{l}\text { Statistical analysis,. Design } \\
\text { of study. }\end{array}$ & \\
\hline 2 & Irfan Younus & $\begin{array}{l}\text { Critical revision of study, Data } \\
\text { Collection. }\end{array}$ & \\
\hline 3 & Sohail Yousuf & Drafting, Data collection. & \\
\hline 4 & Muhammad Javed & $\begin{array}{l}\text { Critical revision, Data } \\
\text { collection. }\end{array}$ & \\
\hline 5 & Khalil lqbal & Critical revision, Data & \\
\hline 6 & Faiza Altaf & Data collection. & \\
\hline
\end{tabular}

